\title{
Aechmea Ruiz \& Pavón from the northern portion of the Atlantic Forest
}

\author{
Jefferson Rodrigues Maciel ${ }^{1,2,4}$, Rafael Louzada ${ }^{2} \&$ Marccus Alves $^{2,3}$
}

\begin{abstract}
Herein we present a taxonomic synopsis of Aechmea species from Alagoas, Pernambuco, Paraíba, Rio Grande do Norte and Ceará states. The lack of a taxonomic key for identification of species, the high rate of endemism and the recent novelties published within Aechmea from this region motivated this work. Samplings were conducted in areas of all states studied between 2010 and 2014. We identified 27 species in the study areas while two names were excluded from the species list compiled from the literature. The subgenus Aechmea was the most representative with 20 species. Of particular importance was the Gravisia complex, represented by ten of the 14 species that form this informal taxonomic group. Pernambuco and Alagoas were the most species-rich compared to the other states. For each species found in the study area, we present identification keys, comments on the taxonomic relationships, habitat information and geographical distribution.

Key words: Bromeliaceae, Poales, taxonomy, morphology.
\end{abstract}

\section{Introduction}

Aechmea Ruiz \& Pavon comprises nearly 250 species distributed in eight subgenera and is one of the most representative genera of Bromelioideae (Forzza et al. 2014; Smith \& Downs 1979). The species occur from Mexico to southern Brazil, Uruguay and northern Argentina (Butcher \& Gouda cont. upd.; Forzza et al. 2014; Smith \& Downs 1979). In the Atlantic Forest, 140 species have been cited (Martinelli et al. 2008; Forzza et al. 2014), which represents more than $50 \%$ of the species richness of Aechmea.

The relationships among lineages within Aechmea are still unclear (Givnish et al. 2014, 2011; Sass \& Specht 2010; Schulte et al. 2009; Horres et al. 2007; Givnish et al. 2007; Schulte et al. 2005), reflecting the traditional difficulties in classifying and establishing a precise definition of the genus (Faria et al. 2010; Wendt 1997; Smith \& Downs 1979). However, the delimitation proposed by Smith \& Downs (1979) has been largely used in taxonomic studies (Butcher \& Gouda cont. upd., Forzza et al. 2014; Aguirre-Santoro \& Betancur 2008; Martinelli et al. 2008; Martins et al. 2007).
In the northern portion of the Atlantic Forest, Sousa \& Wanderley (2000) recorded ten species of Aechmea for the state of Pernambuco and later, Leme $\&$ Siqueira-Filho (2006) found 23 species in the states of Pernambuco and Alagoas. Martinelli et al. (2008) recognized Pernambuco and Alagoas as a region with high diversity and endemism of Bromeliaceae within the Atlantic Forest which was confirmed by Maciel et al. (2015).

The Atlantic Forest fragments have not yet received enough attention concerning their diversity of bromeliads, especially in the Brazilian Northeast. These forest remnants exhibit a range of edaphic, geomorphological and altitudinal aspects (Ferraz \& Rodal 2008). Sometimes these remnants can be found inserted in a semiarid matrix and are locally known as "brejos de altitude" (Thomas \& Barbosa 2008). In this region, recent discoveries have expanded the geographical distribution of species (Magalhães et al. 2014) and new taxa have been described (Leme $\&$ Scharf 2011). Furthermore, recent advances in our knowledge of Aechmea phylogeny have indicated the role of biogeography on the systematics of the genus (Sass \& Specht 2010), highlighting the importance of regional taxonomic studies.

\footnotetext{
${ }^{1}$ Prefeitura da Cidade do Recife, Jardim Botânico do Recife, Km 7,5 da BR 232, s/n, Curado, 50000-230, Recife, PE, Brasil.

${ }^{2}$ Universidade Federal de Pernambuco, Laboratório de Morfo-Taxonomia Vegetal, Av. Moraes Rego, s.n., CDU, 50670-930, Recife, PE, Brasil.

${ }^{3}$ Temporary address: Senckenberg Naturmuseum. 60325, Frankfurt am Main, Germany.

${ }^{4}$ Author for correspondence: jeff.r.maciel@gmail.com
} 
In this work, we studied Aechmea species from the northern part of the Atlantic Forest (Alagoas, Pernambuco, Paraíba, Rio Grande do Norte and Ceará states) and provide identification keys as well as geographical and ecological information for the species.

\section{Material and Methods}

Field work was performed from December 2010 to July 2014 in montane, submontane and lowland Atlantic Forest fragments from Alagoas, Ceará, Paraíba, Pernambuco and Rio Grande do Norte states. We have included the "brejos de altitude" in our study area, although they are not recognized as part of the Atlantic Forest (Thomas \& Barbosa 2008).

Voucher specimens were deposited at UFP herbarium and duplicates sent to RB and NY. Collections at ALCB, ASE, CEPEC, EAC, HRB, HUEFS, IAN, INPA, IPA, JPB, MAC, MBML, MIRR, MPEG, NY, PEUFR, RB, UFP, UFRN, UFRR, US and VIES were also analyzed. To confirm species identification, protologs and type specimens were consulted.

\section{Results and Discussion}

We registered 27 species of Aechmea in Alagoas (17 spp.), Pernambuco (20 spp.), Paraíba
(12 spp.), Rio Grande do Norte (3 spp.) and Ceará (4 spp.) states. Species richness decreases from south to north, reflecting on a local scale the same pattern discussed by Martinelli et al. (2008) for the Atlantic Forest. No specimens were found to confirm the occurrence of $A$. marauensis Leme cited to Alagoas, Pernambuco and Paraiba (Forzza et al. 2014). Aechmea conifera L.B. Smith was also excluded because the specimens cited by Sousa \& Wanderley (2000) belong to $A$. serragrandensis Leme \& J.A. Siqueira-Filho. Thus, A. conifera and A. marauensis are now restricted to Bahia.

Among the 27 species recorded here, Aechmea subg. Aechmea Baker is represented by 20 species, A. subg. Chevaliera (Gaudichaud ex Beer) Baker by four, and Aechmea subg. Lamprococcus (Beer) Baker, A. subg. Macrochordion (De Vriese) Baker, and $A$. subg. Pothuava (Baker) Baker by one species each.

The Gravisia species complex (Read \& Luther 1991 ) is the richest informal taxonomic group in the study area with 10 of the 14 species recognized as belonging to this complex by Leme \& Siqueira-Filho (2006) and Read \& Luther (1991). The Aechmea lingulata complex is represented in the area by four species. This taxonomic complex combines 21 species distributed in the Caatinga and Atlantic Forest of Brazil and the Caribbean (Leme \& Siqueira-Filho 2006).

\section{Key to the Species of Aechmea from the northern Atlantic Forest}

1. Leaf blade margins entire. 18. Aechmea marginalis

1'. Leaf blade margins dentate or serrulate

2. Leaf blades variegated

2. Aechmea atrovittata

2 '. Leaf blades green on both surfaces or adaxially green and abaxially vinaceous

3. Inflorescences simple

4. Floral bracts absent; inflorescence axis wholly exposed 22. Aechmea nudicaulis

4'. Floral bracts present; inflorescence axis completely hidden by bracts

5. Leaves shorter or nearly as long as the inflorescence, 20-60 cm long 3. Aechmea bromeliifolia var. bromeliifolia

5'. Leaves much longer than the inflorescence, $65-220 \mathrm{~cm}$ long

6. Inflorescences $11-15 \mathrm{~cm}$ long, fertile part $7.5 \mathrm{~cm}$ long

14. Aechmea gustavoi

6'. Inflorescence $60-80 \mathrm{~cm}$ long, fertile part $11-25 \mathrm{~cm}$ long

7. Floral bracts with margins densely serrulate

20. Aechmea multiflora

7'. Floral bracts with margins entire

8. Inflorescences glaucous; floral bracts $1.9-2.8 \mathrm{~cm} \times 1-1.4 \mathrm{~cm} \ldots \ldots .$. 21. Aechmea muricata

8'. Inflorescences yellow; floral bracts $7-7.5 \mathrm{~cm} \times 3.8-4.5 \mathrm{~cm}$ 25. Aechmea serragrandensis 
3'. Inflorescences compound

9. Floral bracts $\geq 1 \mathrm{~cm}$ long

10. Inflorescence 10-12 branched

11. Primary bracts as long as or longer than the basal branches, erect, suberect or reflexed

12. Primary bracts suberect to erect; floral bracts $1.2-1.4 \mathrm{~cm}$ long; pedicels $4-5 \mathrm{~mm}$ long.

5. Aechmea catendensis

12'. Primary bracts reflexed; floral bracts $1.5-2 \mathrm{~cm}$ long; pedicels $1-2.5 \mathrm{~mm}$ long.......

9. Aechmea emmerichiae

11'. Primary bracts distinctly shorter than the basal branches, divergent

13. Leaf blade apex attenuate, acute; primary bracts ovate-lanceolate; floral bracts much shorter than the internodes

10. Aechmea eurycorymbus

13'. Leaf blade apex truncate, pungent; primary bracts ovate; floral bracts slightly longer than the internodes

10'. Inflorescence 4-8 branched

14. Peduncle bracts green; branches spreading; rachis partly exposed, sepals yellow

6. Aechmea cephaloides

14'. Peduncle bracts red or orange; branches erect; rachis hidden, sepals orange

15. Inflorescence orange; fertile part 19-25 cm long; peduncle bracts orange; primary bracts divergent with the branches.

1. Aechmea aquilega

15 . Inflorescence yellow; fertile part 8-16 cm long; peduncle bracts red; primary bracts erect

16. Fertile part of inflorescence $8 \mathrm{~cm}$ long; primary bracts yellow....

15. Aechmea lactifera

16'. Fertile part of inflorescence $12-16 \mathrm{~cm}$ long; primary bracts red

7. Aechmea chrysocoma

9'. Floral bracts $<1 \mathrm{~cm}$ long or absent

17. Flowers pedicellate

18. Peduncle bracts divergent, imbricate; primary bracts ovate, apex pungent

8'. Peduncle bracts erect, remote; primary bracts elliptic, apex acute

19. Terrestrial or rupicolous; leaves $33-65 \mathrm{~cm}$ long; leaf blade laxly serrulate; inflorescence pinkish; primary bracts red; sepals elliptical

16. Aechmea leptantha

19'. Epiphytic; leaves $70-110 \mathrm{~cm}$ long; leaf blade laxly dentate; inflorescence red; primary bracts yellow; sepals oblong 27. Aechmea werdermannii

17'. Flowers sessile

20. Inflorescence branched only at basal portion, red; leaf blades adaxially green and abaxially vinaceous

12. Aechmea fulgens

20'. Inflorescence branched from base to apex, yellow, red, green or white; leaf blades green

21. Flowering plant $20-50 \mathrm{~cm}$ tall, forming a tubular to narrowly funnelform rosette with 6-8 leaves; inflorescence 30-40 cm long, fertile part 5.5-16 cm long; branches $1.5-2 \mathrm{~cm}$ long

19. Aechmea mertensii

21 '. Flowering plant $60-170 \mathrm{~cm}$ tall, forming a tubular, crateriform or infundibuliform rosette with 8-20 leaves; inflorescence $53-120 \mathrm{~cm}$ long, fertile part $15-70 \mathrm{~cm}$ long; branches $5-26 \mathrm{~cm}$ long

22. Fertile part of inflorescence $50-70 \mathrm{~cm}$ long; with $80-100$ branches

4. Aechmea castelnavii

22'. Fertile part of inflorescence 15-54 cm long; with 4-28 branches

23. Primary bracts as long as the branches or exceeding them, pink or red .

26. Aechmea tomentosa

23'. Primary bracts reduced or shorter than the axillary branches, green

24. Blade prickles 1.5-3 mm long; inflorescence branches $15-26 \mathrm{~cm}$ long 23. Aechmea patentissima

24'. Blade prickles $0.5-2 \mathrm{~mm}$ long; inflorescence branches 5-12 cm long 
25. Inflorescence with $20-22$ branches

25 '. Inflorescence with $6-16$ branches

26. Leaf sheath $16-21 \mathrm{~cm}$ long; leaf blade $62-110 \times 3.5-5 \mathrm{~cm}$, margins laxly to subdensely serrulate; inflorescence green to red 11. Aechmea froesii

26. Leaf sheath $11-13 \mathrm{~cm}$ long; leaf blade $39-70 \times 8-10 \mathrm{~cm}$, margins densely serrulate; inflorescence whitish 17. Aechmea maranguapensis

\section{Aechmea Ruiz \& Pavon}

Terricolous, rupicolous or epiphytic plants, short- or long-caulescent, forming a tubular, narrowly funnelform, funnelform, broadly funnelform, crateriform or utriculate rosette. Leaves much shorter than the inflorescence to much exceeding the inflorescence; sheaths broadly ovate to elliptical; blades lanceolate to ligulate, green on both surfaces, adaxially variegated or abaxially vinaceous, erect, arching or recurving, glabrous to densely lepidote, apex attenuate, rounded, truncate, obtuse or emarginate, acute to pungent, margins entire to densely serrulate, prickles antrorse, straight or retrorse. Inflorescences simple or compound, capitate, globose, ovoid, ellipsoid, subcylindrical or paniculate, brown, whitish, pinkish, yellow, green, vinaceous, orange, red or glaucous; peduncle bracts remotely to densely imbricate, orange, red, pink, brown, glaucous, green or castaneous; primary bracts erect to divergent with the branches or reflexed, remotely to densely-imbricate, linear-lanceolate to ovate, entire to serrulate, shorter than the secondary peduncle to exceeding the branches, yellow, red, green, pink or orange; erect, spreading or curved; rachis hidden to wholly exposed; floral bracts ample to absent, much shorter than the internodes to exceeding the internodes remotely to very densely imbricate, membranaceous, chartaceous, stiffchartaceous, coriaceous or stiff-coriaceous, glabrous to very densely lepidote, orange, white, green, red, brown, pink, glaucous or yellow. Flowers contiguous to spreading to a right angle with the rachis, sessile to long-pedicellate; sepals obovate to ovate-lanceolate, membranaceous to coriaceous, apex rounded to pungent, glabrous to densely lepidote, pink, white, green, yellow, orange or lilac.

1. Aechmea aquilega (Salisb.) Griseb., Fl. Brit. W.I.: 592. 1864.

Fig. 1a

Selected specimens: ALAGOAS: Campo Alegre, 27.XII.2000, I. Bayma 522 (MAC); CEARÁ: Guaramiranga, 22.IV.2013, J.R. Maciel et al. 1709 (UFP); PARAIIBA: Mamanguape, $05^{\circ} 56^{\prime} 01^{\prime} \mathrm{S}, 35^{\circ} 05^{\prime} 56^{\prime} \mathrm{W}$, 01.V.2005, R.A. Pontes \& P. Gadelha-Neto 216 (JPB, RB) PERNAMBUCO: Jaboatão dos Guararapes,
Engenho Comporta, 12.VII.2005, J.A. Siqueira-Filho et al. 1512 (UFP); RIO GRANDE DO NORTE: São Miguel do Gostoso, 08.VIII.2013, J.R. Maciel \& T. Capistrano 1775 (UFP).

This species occurs from the Caribbean to Brazil, in the Amazon and Atlantic Forest or in dry lands of the Caatinga. In the study area it is cited to Ceará, Rio Grande do Norte, Paraíba, Pernambuco, Sergipe and Alagoas (Forzza et al. 2014; Leme \& Siqueira-Filho 2006; Read \& Luther 1991). It grows in open areas as an epiphytic or terrestrial plant, but it is also tolerant of shady habitats. It can be differentiated from other species of Aechmea in the study area by its orange inflorescences with fertile part around $20 \mathrm{~cm}$ long, peduncle bracts orange and primary bracts divergent with the branches. Moreover, its leaves are as long as the inflorescence, primary bracts are reflexed and longer than the branches. It belongs to the Gravisia complex (Read \& Luther 1991) and due to its morphological variation in inflorescence and habit many taxa have been described and later recognized as synonyms (Leme \& Siqueira-Filho 2006; Sousa \& Wanderley 2000; Read \& Luther 1991; Smith \& Downs 1979).

2. Aechmea atrovittata Leme \& J.A.Siqueira, Fragm. Mata Atlântica do Nordeste: 228. 2006.

Fig. 1b-c

Specimens examined: ALAGOAS: Paripueira, Sítio Laranjeiras, 04.I.2001, J.A. Siqueira-Filho \& A.Frassy (UFP-isotype); ibidem, 31.I.2012, J.A. Siqueira-Filho et al. 2746 (HVASF).

Endemic to the state of Alagoas and known only from the type locality. It grows as an epiphyte in the lowland Atlantic Forest. Leme \& SiqueiraFilho (2006) highlighted the heavily impacted conditions of its habitat in Alagoas, where the only known population is recorded and put it under risk of extinction. It can be differentiated from other species in this study by its variegated leaves, long caulescent growth form and fasciculated inflorescence. It is morphologically related to $A$. disjuncta (L.B. Sm.) Leme \& J.A. Siqueira and cited under the complex A. fosteriana by Leme \& Siqueira-Filho (2006). 
3. Aechmea bromeliifolia var. bromeliifolia (Rudge) Baker in Bentham \& Hooker f., Gen. Pl. 3(2): 664. 1883.

Fig. 1d-e

Selected specimens: CEARÁ: Barbalha, Floresta Nacional do Araripe, 16.XII.2000, I. Costa 117 (EAC); Guaramiranga, Serra do Baturité, 22.VI.2013, J.R. Maciel et al. 1708 (UFP); PARAÍBA: Areia, Campus II da UFPB, 20.VII.2005, R. Pontes 327 (JPB).

It occurs from Central America to northwestern South America and Brazil (Faria et al. 2010). In the study area it is found in Ceará and Paraíba. It grows as an epiphytic or terrestrial plant in Cerrado, Caatinga, Atlantic and Amazonian Forests and in coastal sandy soils (Faria et al. 2010). It can be characterized by its leaves shorter or nearly as long as the inflorescence, which differentiates this species from $A$. subg. Chevaliera. Moreover A. bromeliifolia has densely lepidote floral bracts and white or brown inflorescences. It belongs to A. subg. Macrochordion (Baker) de Vrieese and two varieties are accepted by Faria et al. (2010): A. bromeliifolia var. albobracteata Philcox and $A$. bromeliifolia var. bromeliifolia, the latter is found in the study area based on its known geographical distribution and pink peduncle bracts.

\section{Aechmea castelnavii Baker, Handb. Bromel. 39:} 1889.

Fig. 1f

Selected specimens: CEARÁ: Aquiraz, Rio Pacoti, 15.X.1935, F. Drouet 2616 (US); Itapipoca, Serra dos Picos, 13.I.2006, D. Lima (EAC-49556); Viçosa do Ceará, Serra das Flores, 4.VIII.2005, L.Lima-Verde et al. 3401 (EAC).

This species occurs from Costa Rica to Bolivia and Brazil (Smith \& Downs 1979), where it grows in the Atlantic and Amazonian Forests (Forzza et al. 2014; Smith \& Downs 1979) as an epiphyte in open or shaded places. In the study area, it is recorded only from Ceará state. It has a very long pinkish inflorescence, with up to 80-100 branches. These characters are unique among other species in this study.

5. Aechmea catendensis J.A.Siqueira \& Leme, Fragm. Mata Atlântica do Nordeste: 205. 2006.

Fig. $1 \mathrm{~g}$

Selected specimens: ALAGOAS: Ibateguara, Engenho Coimbra, 09.IX.2002, M.A. Oliveira \& A. Grilo 1096 (UFP), Matriz de Camaragibe, Serra da Curitiba, 26.X.2005, R. Lyra-Lemos 9107 (MAC); PERNAMBUCO: Jaqueira, Serra do Urubu, 08. IX.2000, J.A. Siqueira-Filho 1090 (UFP-holotype); Maraial, Engenho Curtume, 23.XII.2007, M. SobralLeite 609 (UFP).
Endemic to Pernambuco and Alagoas, this species occurs in a very restricted area. It is a terricolous or rupicolous plant, growing in open areas of rocky outcrops within the Atlantic Forest. Leme \& Siqueira-Filho (2006) suggested it as part of the Gravisia complex. It is morphologically related to A. emmerichiae, but can be distinguished by the suberect to erect primary bracts (vs. reflexed in A. emmerichiae); $1.2-1.4 \mathrm{~cm}$ long floral bracts (vs. $1.5-2 \mathrm{~cm}$ long) and $3-3.2 \mathrm{~cm}$ long flowers (vs. $3.5-4 \mathrm{~cm}$ long).

6. Aechmea cephaloides J.A.Siqueira \& Leme, Fragm. Mata Atlântica do Nordeste: 202. 2006.

Fig. $1 \mathrm{~h}$

Selected specimens: PERNAMBUCO: Caruaru, Parque Municipal Prof. Vasconcelos Sobrinho, 9.II.2000, J.A. Siqueira-Filho et al. 1013 (UFP); Lagoa dos Gatos, Sítio Veloso, 6.VI.1999, J.A. Siqueira-Filho et al. 939 (UFP-isotype); Taquaritinga do Norte, Mata da Torre de Microondas, 3.II.2005, J.A. Siqueira-Filho et al. 1458 (UFP).

Endemic to the state of Pernambuco. It grows as a terrestrial plant in shaded Atlantic Forest (Leme \& Siqueira-Filho 2006). Among the taxa of the Gravisia complex, it has a more massive inflorescence and larger rosette. Its inflorescence is globose due to the very congested apical branches and the basal branches are patents with ascendant flowers. It also has crateriform rosettes and inflorescences shorter than the leaves.

7. Aechmea chrysocoma Baker, Handb. Bromel.: 44. 1889.

Fig. 1i

Selected specimens: ALAGOAS: Marechal Deodoro, 20.II.1999, I. Bayma \& C. Barros 192 (MAC); PARAÍBA: Maturéia, 27.IX.1997, M.F. Agra 4286 (JPB); PERNAMBUCO: Goiana, Estação Experimental do IPA, 27.II.1996, G. Sousa 177 (UFP).

Endemic to the northeastern São Francisco River area, where it occurs in Paraiba, Pernambuco and Alagoas states. It grows as an epiphytic or terrestrial plant in shaded places from the Atlantic Forest. It has a yellow inflorescence with a $12-16 \mathrm{~cm}$ long fertile part, red peduncle bracts and red and erect primary bracts. The name was revalidated by Leme $\&$ Siqueira-Filho (2006) and the species also belongs to the Gravisia complex. Originally, it was described by Baker (1889), then accepted as a variety under A. aquilega by Smith \& Downs (1979) and finally as synonymous with $A$. aquilega by Read \& Luther (1991). However, it is clear that the Gravisia complex requires new approaches for a better taxonomic delimitation of the taxa within this informal group. 
8. Aechmea costantinii (Mez) L.B.Sm., Phytologia 19: 281.1970.

Fig. 1j

Selected specimens: ALAGOAS: Ibateguara, Engenho Coimbra, 01.VIII.2003, J.A. Siqueira Filho et al. 1390 (UFP); PARAÍBA: Areia, Reserva Ecológica Estadual Mata do Pau Ferro, 15.VI.1999, G. Baracho 836 (UFP); PERNAMBUCO: Bezerros, Reserva de Serra Negra de Bezerros, 4.III.1996, G. Sousa et al. 181 (UFP).

Endemic to the northeastern São Francisco River area. Epiphytic in shaded and open areas in submontane and montane Atlantic Forest from Paraiba, Pernambuco and Alagoas (Leme \& Siqueira-Filho 2006). Aechmea costantinii is differentiated by the minute floral bracts and pungent primary bracts, yellow inflorescence and flowers, 4-4.5 cm long pedicels and densely lepidote sepals. Sousa \& Wanderley (2000) cited A. stelligera to Pernambuco, which was later synonymized with $A$. costantinii (Leme \& SiqueiraFilho 2006).

9. Aechmea emmerichiae Leme, Bradea 4(39): 309. 1987.

Fig. 2a

Selected specimens: PARAÍBA: Maturéia, Parque Estadual do Pico do Jabre, 15.IV.2005, R. Pontes \& E.A. Rocha 197 (JPB, RB); ibidem, 8.XII.2004, R. Pontes \& N.T. Lima 148 (JPB, RB).

Endemic to northeastern Brazil, where it occurs in Bahia and Paraíba. In the study area it occurs in Paraíba state (Leme \& Siqueira-Filho 2006). It grows in rocky outcrops in montane areas of the Atlantic Forest. It is considered part of the Gravisia complex (Read \& Luther 1991) and closely related to $A$. eurycorymbus and $A$. aquilega. It differs by its inflorescence with 10-12 branches, primary bracts as long as or exceeding the basal branches and 1.5-2 cm long floral bracts.

10. Aechmea eurycorymbus Harms, Notizbl. Bot. Gart. Berlin-Dahlem 12: 528. 1935. Fig. 2b-c Selected specimens: ALAGOAS: Quebrangulo, Reserva Biológica de Pedra Talhada, 12.IV.1994, A.C. Cervi et al. 7416 (NY); PARAÍBA: Campina Grande, 9.X.1948, M.B. Foster 2408 (RB, US); PERNAMBUCO: Ibimirim, 25.II.1961, M. Mee (RB, US-2580048), Triunfo, Lagoa do Mariano, 19.IX.1995, L.P. Félix et al. (HST-7785, HUEFS).

Endemic to the northeastern São Francisco River area. It occurs in Paraíba, Pernambuco and Alagoas as a terrestrial plant in shaded places of the lowland Atlantic Forest. It is morphologically related to $A$. emmerichiae and $A$. guainumbiorum, but can be differentiated by its attenuate and acute leaf blade apices and floral bracts, laxly imbricate peduncle bracts, ovate-lanceolate primary bracts and floral bracts shorter than the internodes. Leme \& Siqueira-Filho (2006) and Sousa \& Wanderley (2000) also emphasized how unclear is the taxonomic limits between $A$. eurycorymbus and $A$. werdermanii are. The main morphological characters to differentiate both species are the length of the floral bracts (1.7-2.5 $\mathrm{cm}$ long in $A$. eurycorymbus vs. $0.6-0.8 \mathrm{~cm}$ long in $A$. werdermanii) and pollen morphology (finely reticulated exine and dense walls vs. broadly reticulated exine and not dense walls) (Leme \& Siqueira-Filho 2006).

11. Aechmea froesii (L.B.Sm.) Leme \& J.A.Siqueira, Fragm. Mata Atlântica do Nordeste: 225. 2006.

Fig. 2d

Selected specimens: ALAGOAS: Ibateguara, Engenho Coimbra, 17.XII.2002, J.A. Siqueira-Filho 1314 (UFP, HVASF); Murici, Fazenda Bananeira, 17.III.2005, J.A. Siqueira-Filho 1474 (UFP); PERNAMBUCO: Ipojuca, Engenho de Pindeirama, 11.XII.1997, S. Tavares 60 (UFP); Sirinhaém, Mata da Laranja, 14.XII.2004, J.A. Siqueira-Filho 1444 (UFP).

Endemic to northeastern Brazil, this species occurs from Pernambuco to Bahia along the Atlantic Forest. In the study area it occurs in Pernambuco and Alagoas. It grows as an epiphytic or terrestrial plant in open or shaded areas. It belongs to the Aechmea lingulata complex (Leme \& SiqueiraFilho 2006) and can be differentiated from the others by its green to red inflorescences with 6-9(14) branches. It often has red inflorescences but this is variable within populations. Smith \& Downs (1979) recognized it as a variety of A. lingulata while Sousa \& Wanderley (2000) accepted no infraspecific taxa under $A$. lingulata. However, Leme \& Siqueira-Filho (2006) proposed a new combination, which is followed here.

12. Aechmea fulgens Brongn., Ann. Sci. Nat., Bot. ser. 2, 15: 371. 1841.

Fig. 2e

Selected specimens: ALAGOAS: Ibateguara, Coimbra, 25.I.2003, M. Oliveira 1240 (UFP); PERNAMBUCO: Jaqueira, RPPN Frei Caneca, 28.IV.2014, J.R. Maciel et al. 1909 (UFP); PARAÍBA: Natuba, Mata da antena da Telemar, 15.V.2005, R. Pontes 246 (JPB).

Endemic to the northeastern São Francisco River area, it occurs as a terrestrial and sometimes epiphytic plant in shaded places in the Atlantic Forest in Paraíba, Pernambuco and Alagoas states. Among the caulescent species in this study, it can be differentiated by its green or adaxially green and abaxially vinaceous leaves, branched and red 


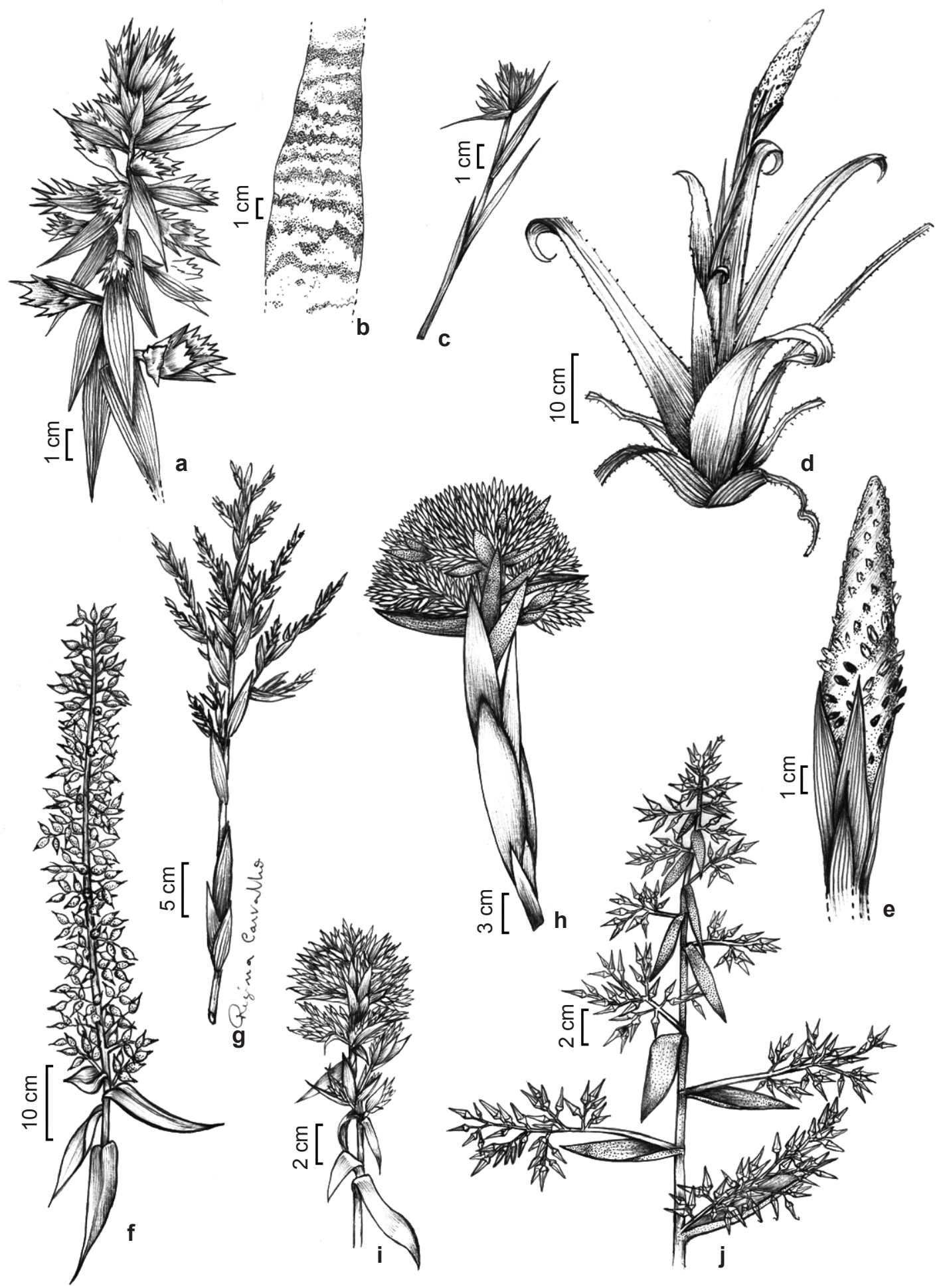

Figure 1 - Species of the Aechmea. a. A. aquilega - fertile part of inflorescence. b-c. A. atrovittata - b. leaf blade; c. inflorescence. d-e. A. bromeliifolia var. bromeliifolia - d. fertile part of inflorescence; e. habit. f. A. castelnaviifertile part of inflorescence. g. A. catendensis - inflorescence. h. A. cephaloides - inflorescence. i. A. chrysocoma - fertile part of inflorescence. j. A. costantinii-fertile portion of inflorescence. 
inflorescence, sessile flowers and lilac sepals. Smith \& Downs (1979) proposed two varieties based on the chromatic pattern of the leaves, which were recognized neither by Sousa \& Wanderley (2000) nor Leme \& Siqueira-Filho (2006).

13. Aechmea guainumbiorum J.A.Siqueira \& Leme, Fragm. Mata Atlântica do Nordeste. 207. 2006.

Fig. $2 \mathrm{f}$

Selected specimens: PERNAMBUCO: Maraial, Engenho Curtume, 2.XI.2001, J.A. Siqueira-Filho 1184 (UFP-holotype); ibidem, 24.X.2006, M.Sobral-Leite 235 (UFP).

Endemic to the state of Pernambuco. Rupicolous in exposed rock outcrops in submontane Atlantic Forest at 500-700 m altitude. Closely related to A. eurycorymbus, from which it differs by its truncate and pungent leaf blade apex, the remote basal-most peduncle bracts and the imbricate uppermost peduncle bracts; ovate primary bracts and floral bracts slightly exceeding the internodes. According to Leme \& Siqueira-Filho (2006), this species belongs to the Gravisia complex.

14. Aechmea gustavoi J.A.Siqueira \& Leme, Selbyana 22(2): 147. $2001 . \quad$ Fig. 2g-h Specimens examined: PERNAMBUCO, Jaqueira, Serra do Urubu, 08.IX.2000, J.A. Siqueira-Filho 1091 (UFP-holotype); ibidem, 29.IV.2014, J.R. Maciel et al. 1929 (UFP).

Endemic to northeastern Brazil and occurring in Bahia and Pernambuco, in submontane Atlantic Forest at 500 to $600 \mathrm{~m}$ altitude. In the study area it is restricted to Pernambuco. It is an epiphyte of canopy trees at $10 \mathrm{~m}$ above the ground and in shaded areas. It is very distinctive due to its capitate inflorescence and the short fertile portion fully inserted in the rosette. Leme \& Siqueira-Filho (2006) related this inflorescence pattern to species of Neoregelia subg. Protoregelia, but morphological characters leave no doubt of its systematic position. Sousa (2004) and Leme \& Siqueira-Filho (2006) indicated some more populations in the states of Pernambuco and Alagoas, however the species has not yet been collected in these areas.

15. Aechmea lactifera Leme \& J.A.Siqueira, Fragm. Mata Atlântica do Nordeste: 199. 2006.

Fig. $2 \mathrm{i}$

Selected specimens: ALAGOAS: Maceió, XI.2000, R. Menescal (CEPEC); PERNAMBUCO: Ipojuca, Fazenda Merepe, 13.I.1997, J.A. Siqueira-Filho 796 (UFP-holotype); idem, Mata do Cupe, 26.V.2013, J.R. Maciel et al. 1734 (UFP).
Endemic to the northeastern São Francisco River area, it occurs in Pernambuco and Alagoas states. Epiphytic or terrestrial plants in shaded areas in lowland Atlantic Forest. It is morphologically related to A. chrysocoma, but is differentiated by the shorter fertile part of inflorescence $(8 \mathrm{~cm}$ vs. $12-16 \mathrm{~cm}$ long) and yellow primary bracts (vs red). A dense milky mucilage can be found on the inflorescence during anthesis resembling latex. Siqueira-Filho \& Leme (2006) stressed this character as a main feature to distinguish this species but it cannot be used with herbarium specimens, which lack this data on the label. Furthermore, A. lactifera is not the only species that has this milky mucilage; it has also been recorded in A. chrysocoma and A. aquilega.

16. Aechmea leptantha (Harms) Leme \& J.A.Siqueira, Fragm. Mata Atlântica do Nordeste: 213. 2006. Fig. $2 \mathrm{j}-\mathrm{k}$ Selected specimens: ALAGOAS: São José da Laje, Usina Serra Grande, 27.II.2002, M. Oliveira 780 (IPA); PARAÍBA: Mamanguape, Reserva Biológica Guaribas, 21.VII.2010, R. Pontes 470 (JPB); PERNAMBUCO: Jaqueira, Reserva Particular do Patrimônio Natural Frei Caneca, 29.VI.2014, J.R. Maciel et al. 1925 (UFP).

Endemic to northeastern Brazil from Paraiba to Sergipe. In the study area it occurs in Paraíba, Pernambuco and Alagoas. Rupicolous in exposed rock outcrops in the Atlantic Forest and Caatinga. The combination of a pinkish, large and lax inflorescence with pedicellate flowers and red primary bracts is unique among the studied species. Leme \& Siqueira-Filho (2006) placed this taxon under Aechmea (previously described as Portea leptantha Harms) based on morphological evidence, but recently Sass \& Specht (2010) have confirmed its affinity to Portea species based on molecular evidence. Herein, we follow Forzza et al. (2014) and Leme \& Siqueira-Filho (2006), who used morphological characters to place this species under Aechmea.

17. Aechmea maranguapensis Leme \& Scharf, Bromelie 2011(2): 59. $2011 . \quad$ Fig. 3a Selected specimens: CEARÁ: Maranguape, Serra do Maranguape, 24.IV.2013, J.R. Maciel et al. 1727 (UFP); ibidem, 26.XI.1955, D. Andrade-Lima \& G. Black (EAC-1536); Pacoti, Sítio Olho D’Água dos Tangarás, 2.XI.1996, L. Lima-Verde 155 (EAC).

Endemic to the state of Ceará and growing as an epiphytic or rupicolous plant in Serra de Maranguape above $700 \mathrm{~m}$ alt. Leme \& Sharf 
(2011) related it to $A$. pernambucentris and $A$. sulbahianensis Leme, Amorim \& J.A. Siqueira. However, based on the studied specimens, it seems to be morphologically related to $A$. froesii in the A. lingulata complex due to its little-branched inflorescence. However, it can be differentiated by its lilac flowers that are purplish at the apex, white inflorescence, shorter sheaths, and shorter and wider leaf blade.

18. Aechmea marginalis Leme \& J.A.Siqueira, Selbyana 22(2): 149. 2001. Fig. 3b Specimen examined: ALAGOAS: Ibateguara, II.2001, J.S. Medeiros \& A. Frassy (HB-holotype).

Endemic to the state of Alagoas and restricted to a small area of lowland Atlantic Forest where grows as an epiphyte. It has a capitate but branched yellow inflorescence and green bracts. However, the main character to recognize it is the entire leaf blade margin, uncommon among species from the area.

19. Aechmea mertensii (G. Mey.) Schult. \& Schult. f. in Roemer \& Schultes, Syst. Veg., ed. 15 bis 7(2): 1272.1830 .

Fig. 3c

Selected specimens: ALAGOAS: Ibateguara, Engenho Coimbra, 25.I.2003, M. Oliveira \& A. Grillo 1246 (UFP); PARAIBA: Mamanguape, Reserva Biológica Guaribas, 26.VIII.2010, R.A. Pontes \& J.R. Lima 559 (JPB); PERNAMBUCO: Ipojuca, Oiteiro de Nossa Senhora do Ó, 01.VI.2013, J.R. Maciel et al. 2013 (UFP).

It is cited from Colombia, Peru and Brazil (Smith \& Downs 1979), where it occurs in the Amazon and Atlantic Forest. In the study area it is found from Paraíba to Alagoas. It is epiphytic, often growing in lighted areas and associated with Anthurium gracile Lindl. (Araceae) and ant gardens formed among the roots of both species. It reaches $20-50 \mathrm{~cm}$ tall while blooming, with a tubular to narrowly funnelform rosette and few leaves (6-8). The inflorescence is short-branched, with sessile and yellow flowers. A floral bract enfolding most of the ovary is a unique condition among the species studied here. Sousa \& Wanderley (2000) indicated that the specimens from the Amazon Forest are often more robust. However, we found large and short morphotypes among the studied material. Differences in plant development within $A$. mertensii is common and Leroy et al. (2012) demonstrated that $A$. mertensii plants can develop large and short morphotypes depending on the ant species that colonize its rosette.
20. Aechmea multiflora L.B.Sm., Contr. Gray Herb. 117: 4, pl. 1, figs. 1-3. $1937 . \quad$ Fig. 3d-e Selected specimens: ALAGOAS: Coruripe, Usina Guaxuma, 31.X.2004, J.A. Siqueira-Filho et al. 1436 (UFP); Feliz Deserto, s.1., 4.XI.1979, D. Andrade-Lima 79-8772 (IPA); Maragogi, s.1., 11.X.1980, D. AndradeLima 80-8813 (IPA).

Endemic to Brazil, distributed from Alagoas to Bahia state. In the study area it was recorded only for Alagoas. It is a common species in lowland coastal forest ("restinga") where it grows as a terrestrial plant in sandy soils and shaded places or as an epiphyte. It can be recognized by its massive, globose and red inflorescence with, densely serrulate, red floral bracts. The fruits are edible with a sweet flavor. Canela et al. (2003) pointed out that the inflorescence of $A$. multiflora elongates after anthesis, which differentiates it from $A$. depressa L.B. Sm. Leme \& Siqueira (2001) described $A$. frassyi as related to $A$. multiflora but later the same authors synonymized it (Leme \& Siqueira 2006).

21. Aechmea muricata (Arruda) L.B.Sm., Phytologia 8: 12. 1961 . Fig. 3f-g Selected specimens: ALAGOAS: Paripueira, Sítio Laranjeiras, 04.I.2001, J.A. Siqueira-Filho \& A. Frassy 1147 (UFP); PERNAMBUCO: Cabo de Santo Agostinho, Mata da Pólvora, 01.VI.2013, J.R. Maciel et al. 1745 (UFP); RIO GRANDE DO NORTE: Baía Formosa, Mata Estrela, 24.III.2013, R. Magalhães 19 (UFRN).

Endemic to the northeastern São Francisco River area, restricted to Alagoas, Pernambuco and Rio Grande do Norte (Magalhães et al. 2014). It grows in open and shaded areas as an epiphytic or terricolous plant in lowland Atlantic Forest. It is common in sandy soils along the coast in "restinga" vegetation. It can be characterized by its green and subcylindrical inflorescence. Leme \& Siqueira-Filho (2006) and Sousa \& Wanderley (2000) highlighted the heavy impact on and loss of natural populations in urban areas in the state of Pernambuco.

22. Aechmea nudicaulis var. nordestina J.A.Siqueira \& Leme, Fragm. Mata Atlântica do Nordeste: 243. 2006. Fig. $4 \mathrm{a}$ Selected specimens: PARAÍBA: Salgado de São Félix, Sítio Pau D'árco, 16.IV.2005, R.A. Pontes 164 (RB); Natuba, Fazenda Sr. Gera, 14.V.2005, R. Pontes 254 (JPB). PERNAMBUCO: Gravatá, Sítio Brejo Velho, 5.II.2005, J.A. Siqueira-Filho \& M. Sobral-Leite 1470 (UFP); Macaparana, Pirauá, 02.II.2004, J.A. SiqueiraFilho et al. 1454 (UFP-holotype). 


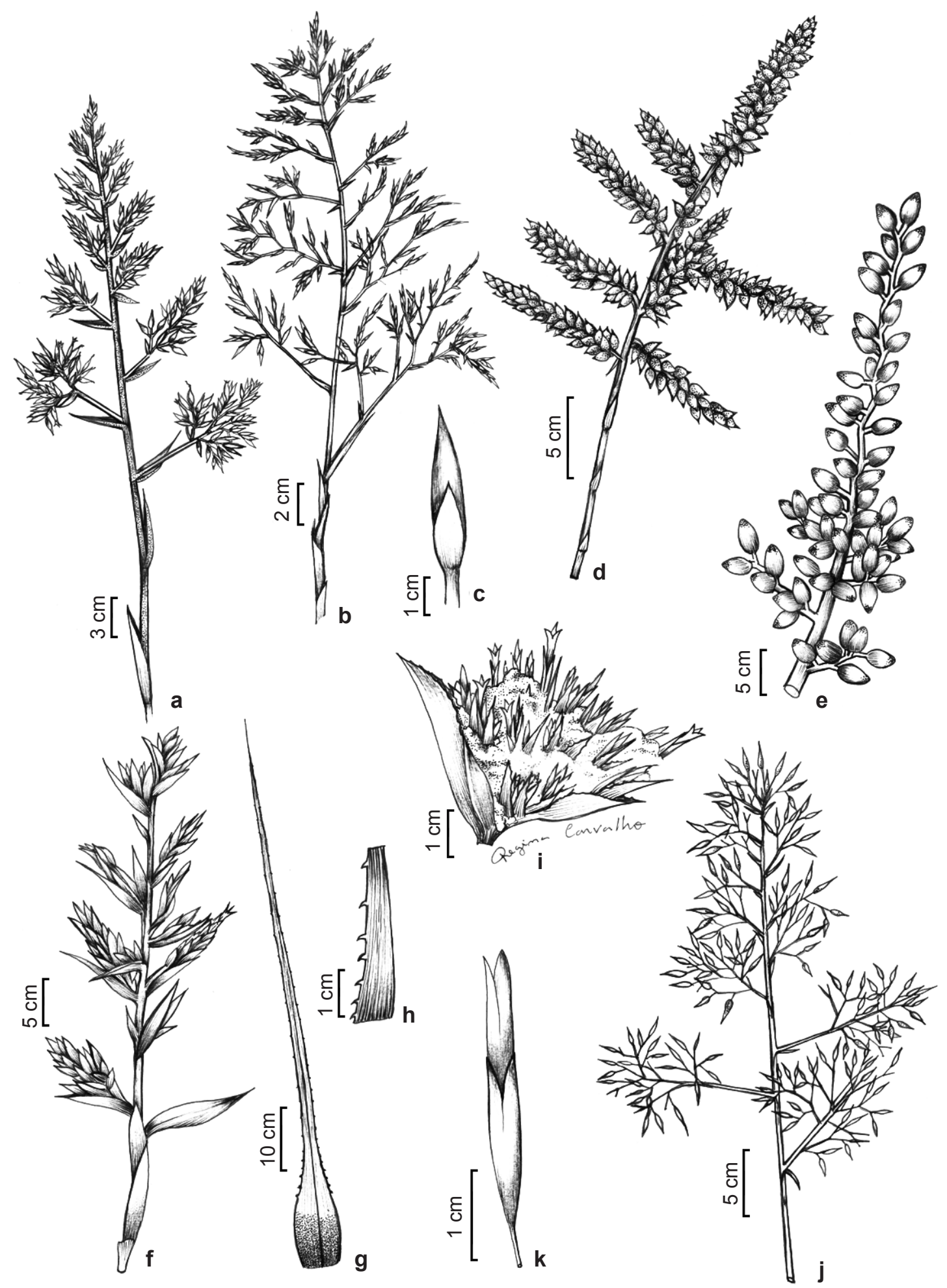

Figure 2 - Species of the Aechmea. a. A. emmerichiae - inflorescence. b-c. A. eurycorymbus - b. inflorescence; c. floral bract view. d. A. froesii - inflorescence. e. A. fulgens - fertile part of inflorescence. f. A. guainumbiorum inflorescence. g-h. A. gustavoi-g. leaf; h. leaf margin detail. i. A. lactifera-i. fascicle of the inflorescence. j-k. A. leptantha $-\mathrm{j}$. fertile part of inflorescence; $\mathrm{k}$. flower. 
Aechmea nudicaulis occurs from Central America to Brazil (Wendt 1997) and A. nudicaulis var. nordestina is one of the varieties recognized. It is endemic to the montane and submontane northern Atlantic Forest and found in the states of Paraíba and Pernambuco (Leme \& Siqueira-Filho 2006). The pale green peduncle bracts, sepals and inflorescence can be used to distinguish this variety (Smith \& Downs 1979). In the study area it can be grouped with the plants with long caulescent growth form, but it has green leaves and a simple, pale green inflorescence with the axis fully exposed.

\section{Aechmea patentissima Baker, J. Bot. 17: 227.} 1879.

Fig. 4b-d

Selected specimens: ALAGOAS: União dos Palmares, Faz. Sto. Antonio, 29.X.2002, J.A. Siqueira-Filho 1290 (UFP); PARAÍBA: Mamanguape, REBIO Guaribas, VIII.2013, J.R. Maciel et al. 1777 (UFP); PERNAMBUCO: Jaqueira, RPPN Frei Caneca, 28.IV.2014, J.R. Maciel et al. 1903 (UFP); RIO GRANDE DO NORTE: Natal, Parque das Dunas, 21.IX.2012, E. Tomaz 1 (UFRN).

In the study area it occurs in Rio Grande do Norte, Paraíba, Pernambuco and Alagoas states, but has a wide distribution in the Atlantic Forest and can also been found in Bahia, Espírito Santo, and Rio de Janeiro. It is terrestrial or epiphytic in shaded or open places. It is related to A. pernambucentris but can be distinguished by the higher number of inflorescence branches. A. patentissima has a longer inflorescence and longer branches than $A$. pernambucentris. Leme \& Siqueira-Filho (2006) restored A. patentissima to species status unlike Smith \& Downs (1979) and Sousa \& Wanderley (2000), who placed $A$. patentissima as a variety of A. lingulata. Leme \& Siqueira-Filho (2006) included this species in the A. lingulata complex and related it to A. lingulatoides Leme \& H. Luther.

24. Aechmea pernambucentris J.A.Siqueira \& Leme, Fragm. Mata Atlântica do Nordeste. 227. 2006.

Fig. $4 \mathrm{e}$

Selected specimens: PERNAMBUCO: Taquaritinga do Norte, 21.IX.1998, G. Baracho 761 (UFP-holotype); Idem, Rampa do Pepê, 16.V.2015, J.R. Maciel \& B.S. Amorim 2027 (UFP); Jaqueira, Mata da Serra do Quengo, 28.IX.1997, J. Siqueira-Filho \& M. Campelo 736 (UFP).

Endemic to the northeastern São Francisco River area and restricted to montane forests of Pernambuco state. It is epiphytic in shaded forest above $700 \mathrm{~m}$ altitude. The inflorescence is highly- branched which resembles $A$. patentissima, but the fertile portion of the inflorescence and branches are shorter. It belongs to the Aechmea lingulata complex (Siqueira-Filho \& Leme 2006) with $A$. froesii, A. maranguapensis and $A$. patentissima.

25. Aechmea serragrandensis Leme \& J.A.Siqueira, Fragm. Mata Atlântica do Nordeste: 241. 2006.

Fig. 4f

Selected specimens: ALAGOAS: Ibateguara, Engenho Coimbra, 02.VI.2005, J.A. Siqueira-Filho et al. 1500 (UFP-holotype); Porto Calvo, Propriedade Eixo, 30.VIII.1969, D. Andrade-Lima 69-5589 (IPA); PERNAMBUCO: Jaqueira, RPPN Frei Caneca, 6.V.2015, J.R. Maciel et al. 2020 (UFP).

Previously recorded just to the state of Alagoas, now the distribution of $A$. serragrandensis is expanded to Pernambuco. It grows as an epiphyte in shaded areas in the lowland and submontane Atlantic Forest. It is very distinctive due to its ovoid or ellipsoid inflorescence with yellow and entire floral bracts. The plants support a big rosette and massive inflorescences. Despite the poor morphological knowledge of $A$. conifera (Sousa 2004), Leme \& Siqueira-Filho (2006) described A. serragrandensis by comparing it to A. conifera. The authors cited A. Lima 69-5589 as a paratype, which was used by Sousa (2004) to recognize A. conifera in the state of Alagoas. Thereby, we excluded recognition of the species $A$. conifera from the study area.

26. Aechmea tomentosa Mez, Monogr. Phan. 9: 229. 1896. Fig. $4 \mathrm{~g}$ Selected specimens: ALAGOAS: Porto Calvo, Eng. Oriente, 14.VIII.1960, D. Andrade-Lima 60-3512 (IPA); Flexeiras, Serra das Águas Belas, 02.XI.2002, W.W. Thomas et al. 13187 (CEPEC, NY); PERNAMBUCO: Ipojuca, Oiteiro de Nossa Senhora do Ó, 01.VI.2013, J.R. Maciel et al. 1744 (UFP); Sirinhaém, Engenho do Anjo, 15.XII.2004, J.A. Siqueira-Filho et al. 1445 (UFP).

Endemic to the northeastern São Francisco River area. It occurs as a terrestrial plant in sandy soil of the lowland Atlantic Forest along the coast of the states of Alagoas and Pernambuco. It grows in shaded areas and is rarely found in open habitats. It has small floral bracts and sessile flowers. It is distinguished by being the only species in the area with cinereous inflorescences, entire and red peduncle bracts and primary bracts and sepals with a $0.5-0.8 \mathrm{~mm}$ long spine. Sousa \& Wanderley (2000) and Leme \& Siqueira-Filho (2006) used the peduncle and flower indument, primary bract 

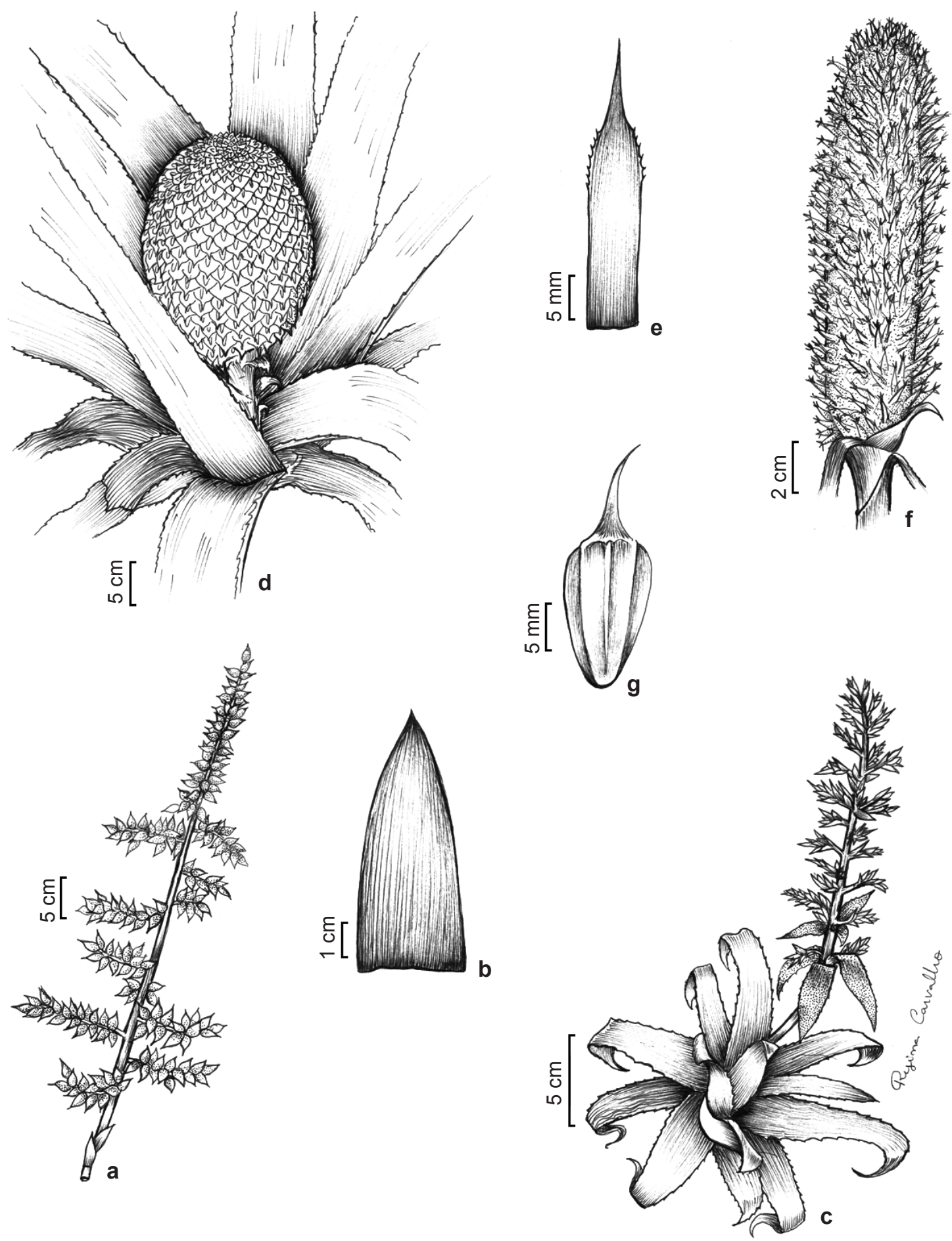

Figure 3 - Species of the Aechmea. a. A. maranguapensis - inflorescence. b. A. marginalis - part of the leaf blade. c. A. mertensii - habit. d-e. A. multiflora - d. habit; e. floral bract. f-g. A. muricata - f. fertile part of inflorescence; g. floral bract. 


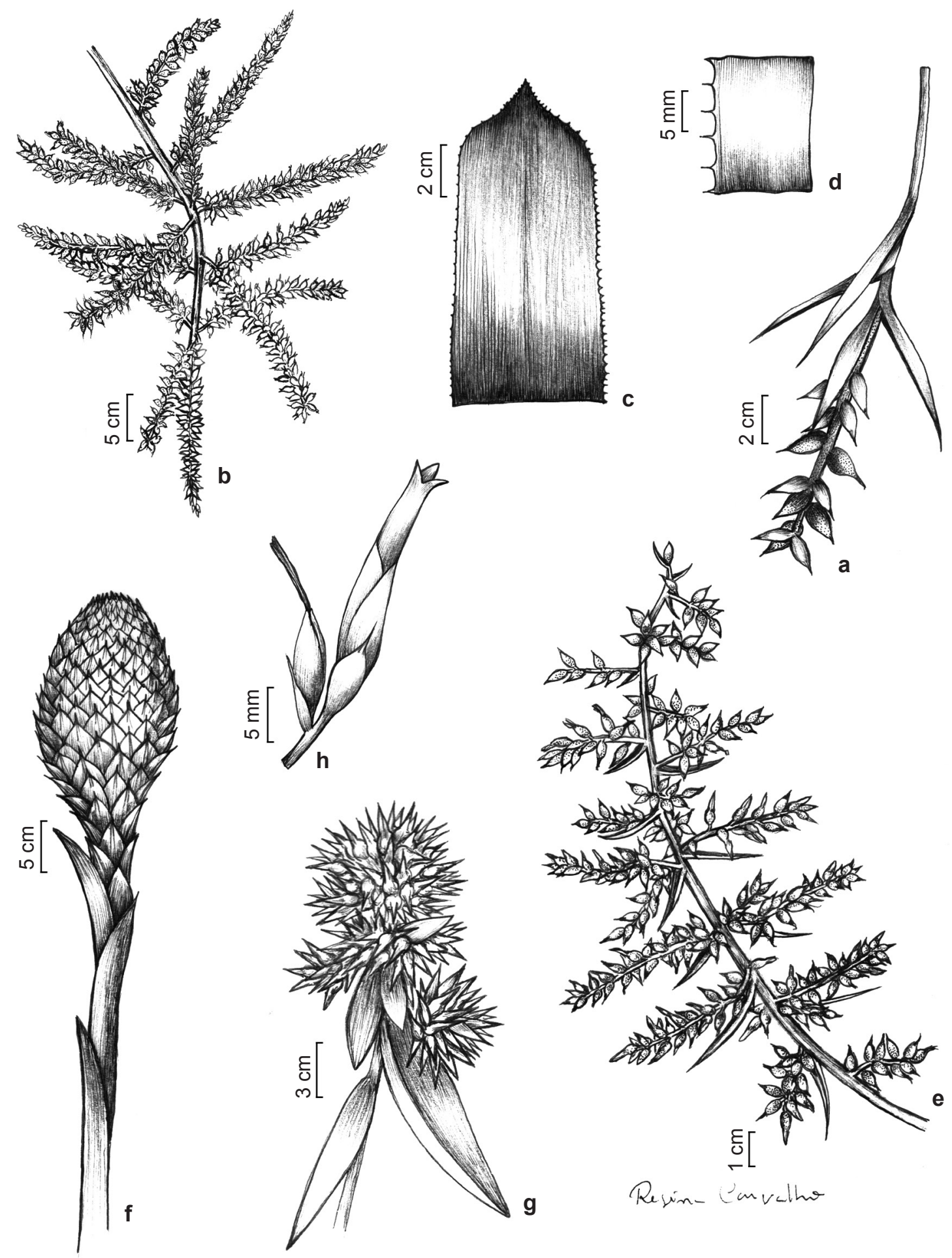

Figure 4 - Species of the Aechmea. a. A. nudicaulis var. nordestina - inflorescence. b-d. A. patentissima - b. inflorescence; c. portion of leaf blade; d. margin detail. e. A. pernambucentris - inflorescence. f. A. serragrandensis - inflorescence. g. A. tomentosa - fertile part of inflorescence. h. A. werdermanii-flower. 
shape, branch arrangement and flower length to distinguish this taxon from $A$. costantinii $(=A$. stelligera) and $A$. werdermanii.

27. Aechmea werdermannii Harms, Notizbl. Bot. Gart. Berlin-Dahlem 12: 529. $1935 . \quad$ Fig. 4h Selected specimens: ALAGOAS: Maceió, s.1., II.2004, E. Leme 4984 (HB); PARAÍBA: São João do Tigre, Quati, 24.V.2006, R.A. Pontes 355 (JPB); PERNAMBUCO: Floresta, Reserva Biológica de Serra Negra, 27.I.2006, J.A. Siqueira-Filho 1550 (UFP).

Endemic to the northeastern São Francisco River area. Epiphytic in montane and submontane Atlantic Forest from Paraiba, Pernambuco and Alagoas. It grows in shaded places. The species is morphologically similar to A. leptantha and $A$. eurycorymbus but differs by its habit (epiphytic) with longer leaves $(70-110 \mathrm{~cm})$ and red inflorescences. Although it was not included by Read \& Luther (1991) under the Gravisia complex, Leme \& Siqueira-Filho (2006) suggested its relationship.

\section{Acknowledgments}

We are indebted to the organizations that funded our field research, including $\mathrm{CNPq}$ (Brazil), the National Science Foundation (USA, DEB0946618), Velux Stiftung (Switzerland), and the Beneficia Foundation (USA). We thank the curators of the consulted herbaria, Regina Carvalho for illustrations and Scott Heald for reviewing the English of the manuscript.

\section{References}

Aguirre-Santoro, J. \& Betancur, J. 2008. Sinopsis del género Aechmea (Bromeliaceae) para Colombia. Caldasia 30:265-288.

Baker J.G. 1889. Handbook of Bromeliaceae. George Bell \& Sons, London. 264p.

Butcher, D. \& Gouda, E. 2013. The new Bromeliad Taxon list. Available at <http://http://botu07. bio.uu.nl/bcg/taxonList.php?\#H>. Access on 16 September 2013.

Canela, M.B.F.; Paz, N.P.L. \& Wendt, T. 2003. Revision of the Aechmea multiflora complex (Bromeliaceae). Botanical Journal of the Linnean Society 143: 189-196.

Faria, A.P.G.; Wendt T. \& Brown, G.K. 2010. A revision of Aechmea subgenus Macrochordion (Bromeliaceae) based on phenetic analyses of morphological variation. Botanical Journal of the Linnean Society 162: 1-27.

Ferraz, E.M.N. \& Rodal, M.J.N. 2008. Floristic characterization of a Remnant Ombrophilous
Montane Forest at São Vicente Férrer, Pernambuco, Brazil. In: Thomas, W.W. The Atlantic Coastal Forest of Northeastern Brazil. New York Botanical Garden Press, New York. Pp. 474-516.

Forzza, R.C.; Costa, A.; Siqueira-Filho, J.A.; Martinelli, G.; Monteiro, R.F.; Santos-Silva, F.; Saraiva, D.P.; Paixão-Souza, B.; Louzada, R.B. \& Versieux, L.M. 2014. Bromeliaceae. In: Lista de Espécies da Flora do Brasil. Jardim Botânico do Rio de Janeiro. Available at $<$ http://reflora.jbrj.gov.br $>$. Access on 7 July 2014.

Givnish T.J.; Barfuss M.H.J.; Van Ee B.; Riina R.; Schulte K.; Horres R.; Gonsiska P.A.; Jabaily R.S.; Crayn D.M.; Smith J.A.C.; Winter K.; Brown G.K.; Evans T.M.; Holst B.K.; Luther H.; Till W.; Zizka G.; Berry P.E. \& Sytsma K.J. 2011. Phylogeny, adaptive radiation, and historical biogeography in Bromeliaceae: insights from an eight-locus plastid phylogeny. American Journal of Botany 98: 872895.

Horres, R.; Zizka, G.; Kahl, G. \& Weising, K. 2000. Molecular Phylogenetics of Bromeliaceae: Evidence from trnL (UAA) Intron Sequences of the Chloroplast Genome. Plant Biology 2: 306-315.

Leme, E.M.C. \& Scharf, U. 2011. Two new species from Atlantic forest of Northeastern Brazil. Die Bromelie 2: 59-69.

Leme, E.M.C. \& Siqueira-Filho, J.A. 2001. Studies in Bromeliaceae of northeastern Brazil I. Selbyana 22: 146-154.

Leme, E.M.C. \& Siqueira-Filho, J.A. 2006. Taxonomia de bromélias dos fragmentos de Mata Atlântica de Pernambuco e Alagoas. In: Siqueira-Filho, J.A. \& Leme, E.M.C. Fragmentos de Mata Atlântica do Nordeste - biodiversidade, conservação e suas bromélias. Andrea Jakobsson Estúdio, Rio de Janeiro. Pp. 191-381.

Leroy, C.; Corbara, B.; Pélozuelo, L.; Carrias, J.; Dejean, A. \& Céréghino, R. 2012. Ant species identity mediates reproductive traits and allocation in an ant-garden bromeliad. Annals of botany 109:145-52.

Maciel, J.; Zizka, G. \& Alves, M. 2015. Searching for the gigantic bromeliads of northeastern Brazil. Die Bromelie 2015: 30-38.

Magalhães, R.; Versieux, L.M. \& Calvente, A. 2014. Aechmea muricata (Arruda) L. B.Sm. (Bromeliaceae: Bromelioideae): a new record of a threatened species for Rio Grande do Norte, Northeastern Brazil. CheckList 10: 434-435.

Martinelli, G.; Vieira, C.M.; Gonzalez, M.; Leitman, P.; Piratininga, A.; Costa, A.F. \& Forzza, R.C. 2008. Bromeliaceae da Mata Atlântica Brasileira: lista de espécies, distribuiçao e conservação. Rodriguésia 59: 209-258.

Martins, S.E.; Wanderley, M.G.L. \& Proença, S.L. 2007. Aechmea Ruiz \& Pav., nom. cons. In: Wanderley, M.G.L.; Shepherd, G.J.; Melhem, T.S. \& Giulietti, 
A.M. Flora Fanerogâmica do Estado de São Paulo. Instituto de Botânica, São Paulo. Vol. 5, pp. 44-59.

Read, R.W. \& Luther, H.E. 1991. The Aechmeal Gravisia complex (Bromeliaceae). Selbyana 12: 54-67.

Sass, C. \& Specht, C.D. 2010. Phylogenetic estimation of the core Bromelioids with an emphasis on the genus Aechmea (Bromeliaceae). Molecular Phylogenetics and Evolution 55: 559-71.

Schulte K.; Barfuss M.H.J. \& Zizka G. 2009. Phylogeny of Bromelioideae (Bromeliaceae) inferred from nuclear and plastid DNA loci reveals the evolution of the tank habit within the subfamily. Molecular Phylogenetics and Evolution 51: 327-39.

Schulte K.; Horres R. \& Zizka G. 2005. Molecular phylogeny of Bromelioideae and its implications on biogeography and the evolution of CAM in the family. Senckenbergiana biologica 15: 1-14.
Smith, L.B. \& Downs, R.J. 1979. Bromelioideae (Bromeliaceae). Flora Neotropica 14: 1493-2142.

Sousa, G.M. \& Wanderley, M.G.L. 2000. Aechmea Ruiz \& Pav. (Bromeliaceae) do Estado de Pernambuco, Brasil. Acta Botanica Brasilica 14: 77-97.

Sousa, G.M. 2004. Revisão taxonômica de Aechmea Ruiz \& Pavon subg. Chevaliera (Gaudich. ex Beer) Baker Bromelioideae-Bromeliaceae. Doctoral Thesis, Universidade de São Paulo, São Paulo. 185p.

Thomas, W.W. \& Barbosa, M.R.V. 2008. Natural vegetation types in the Atlantic Coastal Forest of Northeastern Brazil. In: Thomas, W.W. The Atlantic Coastal Forest of Northeastern Brazil. New York Botanical Garden Press, New York. Pp. 6-20.

Wendt, T. 1997. A review of the subgenus Pothuava (Baker) Baker of Aechmea Ruiz \& Pav. (Bromeliaceae) in Brazil. Botanical Journal of the Linnean Society 125: 245-271.

\section{List of examined material}

Albuquerque, N. 205(19), 499(19); Amorim, B. 819(16), 1122(19); Andrade-Lima, D. \& Black, G. EAC-1536(17); Andrade-Lima, D. 13(26), 38(26), 54-1895(16), 55-2135(21), 57-2738(12), 57-2764(23), 57-2767(19), 57-2769(23), 58-3267(3), 59-3388(26), 59-3395(23), 60-3512(26), 61-3980(16), 63-4177(23), 63-4186(19), 63-4197(21), 65-4318(21), 66-4444(4), 67-4977(12), 69-5541(12), 69-5589(25), 70-5875(3), 72-8224(1), 72-8273(23), 79-8772(20), 80-8813(20); Baracho, G. \& Siqueira-Filho, J. 590/579(1); Baracho, G. 476(12), 517(12), 527(8), 584(23), 588(26), 687(23), 730(23), 738(21), 761(24), 836(8), 837(23); Barbosa, M. 2478(26); Barbosa, V. 182(16); Barreto, R. 82-64(16); Barros, C. et al. 106(1); Barros, R. et al. HST-7820(12); Bayma, I. \& Barros, C. 192(7); Bayma, I. 522(1); Benko-Iseppon, A. et al. 1698(16), 1699(16), 1700(16); Bogner, J. 1195(3); Brasil, R. 230(23); Brito, Z. 18(8); Cano, O. 46a(16); Carvalho, A. 7078(12), 7130(11), 7131(26), 7131(8), 730(23); Castro, A. 2(3), 1981(4); Cervi, A. 7416(10); César, E. 88(23), 89(23), 124(19), 168(23); Costa, A. 8(16), 169(25); Costa, I. 117(3), 347(3), EAC-32341(3); Costa-e-Silva, M. 2853(16); Drouet, F. 2616(4); Ducke, A. IAN-2051(1), IAN-115984(1); Esteves, G. \& Lyra-Lemos, R. 1795(23), 2168(21); Esteves, G. \& Staviski, M. 1715(1); Esteves, G. 2101(19); Fagundes, J. 82(16); Falcão, A. 868(26); Félix, L. 1785(12), 3065(19), 3923(19), 5540(8), 5549(23), 6155(3), 6371(8), 7005(19), EAC-19048(3), EAN-15661(23), HST-17314(12), JPB-15658(19); Félix, L. et al. 7167(26), HST-7785(10); Fernandes, A. EAC-1835(3), EAC-1836(1), EAC-4145(3), EAC-11681(27); Ferreira, E. 254(3), 328(3); Ferreira, P. 45-68(19); Fevereiro, V. 134(8); Fontana, A. 6553(27), 6991(27); Fortunato, M. 59(17), 61(17); Foster, M. 2406(23), 2408(10); Freire, J. 17(23); Gadelha-Neto, P. 815(23), 2999(23), RB-418532(12); García-González, J. 1224(19); Girao-e-Silva, W. EAC-27199(3); Gomes, L. 209(19); Gomes, V. \& Xavier, A. 2109(3); Gomes, V. et al. 353(1), 712(3); Guedes, F. 108(16); Guedes, M. ALCB-92995(23); Krapovickas, A. 38033(16); Leite, M. 236(16), 791(21); Leme, E. \& Siqueira-Filho, J. 6507(7), 6509(23), 6771(23); Leme, E. 3914(17), 5086(20); Leme, E. et al. 6618(19); Lima, D. EAC-49556(4); Lima, J. 2141(3); Lima, R. 1722(8); Lima, V. 96(27), 828(8); Lima-Verde, L. 155(17), 1766(3), 1794(3), 3401(4), EAC-15693(3), EAC-21247(3); Lima-Verde, L. et al. 3444(3); Lopes, A. UFP-22481(26), UFP-22482(21), UFP-21755(12); Luceno, M. UFP-11463(15); Luetzelburg, P. 26461(3), s.n. (Smith \& Downs 1979) (3); Lyra-Lemos, R. \& Staviski, M. 404(19); Lyra-Lemos, R. 2736(19), 4629(19), 5300(26), 5979(19), 6316(12), 8026(19), 9107(5); M.Agra, M. 260(19), 4286(7), 4516(7); Maciel, J. et al. 1708(3), 1709(1), 1727(17),1728(17), 1734(1), 1743(19), 1744(26), 1745(21), 1867(19), 1909(12), 1912(23), 1913(15), 1914(5), 1925(16), 1926(8), 1929(14), 2020(25), 2021(6); Maciel, J. \& Amorim, B. 2027 (24); Maciel, J. \& Capistrano, T. 1770(1), 1775(1); Mariz, G. 493(23); Martinelli, G. 15043(27), 15055(3), 15071(17), 15084(23), 15087(8), 15088(16), 15104(26), 15107(8), 15108(12), 15111(12), 15123(26), 15126(12), 15129(26), 15131(26), 15331(12), 15333(16); Martinelli, G. et al. 15338(11); Matias, L. EAC-27661(17); Medeiros, J. \& Frassy, A. s.n.(18); 
Mee, M. US-2580028(1), US-2580048(10); Meiado, M. 370(16); Melo, A. 110(19), 239(19); Mendonça, E. et al. 46(6); Menescal, R. CEPEC-127566(15); Miranda, C. 3505(23); Monteiro, F. 8(17), 15(17); Montenegro, P. 42(19); Moraes, J. 862(8), 1239(21), EAN-68(8), EAN-1192(23), EAN-1236(12), EAN-1477(22); Nojosa, D. EAC-26148(3); Nunes, E. UFP-18569(26); Oliveira, C. 265(16); Oliveira, J. 03(19),14(26); Oliveira, M. \& Grillo, A. 1096(5),1246(19); Oliveira, M. 898(19), 1238(11), 1240(12), 1246(19), 780(16); Oliveira, R. EAC-27280(17); Oliveira. O. 1467(23); Pereira, E. 868(26); Pereira, M. 114(16); Pereira, R. et al. 766(1); Pereira, R. IPA-53614(16); Pessoa, M. 98(8); Pickel, B. 1281(12), 2233(1), 2298(12), 2488(23), 2992(16), 2995(19), 3059(26), 3457(19), 3536(16), 3657(23); Pontes, R. \& Lima, N. 131(7); Pontes, R. 51(23),84(8), 85(8), 97(23), 98(23), 107(8), 108(8), 110(8), 113(8), 121(23), 132(23), 142(9), 144(9), 145(9), 148(9), 150(9), 156(16), 157(16), 159(16), 162(16), 164(22), 165(22), 166(22), 167(22), 194(9), 195(9), 196(9), 197(9), 198(9), 207(16), 208(16), 210(16), 218(19), 219(19), 220(19), 223(23), 234(10), 244(12), 246(12), 247(12), 249(12), 254(22), 318(8), 327(3), 328(8), 329(8), 332(12), 339(10), 345(10), 346(16), 355(27), 404(8), 415(10), 415(10), 430(27), 470(16), 558(23), 559(19), 577(27), 605(23); Pontual, I. 233(26); Pontual, I. 66-262(23); PPD 223(23); Queiroz, E. 2584(19),2600(7); Rocha, F. 156(23); Rocha, R. et al. 1602(23); Sacramento, A. 50(21),454(19); Segadas-Vianna, F. rest I-279(23); Sevilha, A. 2542(23); Silva, D. 24(27); Silva, J. 388(5); Silva, V. UFP-39360(1); Siqueira-Filho, J. \& Frassy, A. 8(2); Siqueira-Filho, J. \& Leme, E. 1218(1); Siqueira-Filho, J. 478(26), 483(26), 562(12), 592(16), 595(23), 599(16), 600(12), 608(26), 609(21), 696(3), 724(23), 736(24), 742(8), 773(22), 786(16), 796(15), 804(21), 938(5), 942(8), 943(23), 999(19), 1007(26), 1043(8), 1090(5), 1091(14), 1147(21), 1167(5), 1184(13), 1187(15), 1216(21), 1247(26), 1250(8), 1260(27), 1277(27), 1286(12), 1290(23), 1294(8), 1296(21), 1297(8), 1302(8), 1314(11), 1331(8), 1380(8), 1389(16), 1390(8), 1393(12), 1436(20), 1443(21), 1444(11), 1445(26), 1454(22), 1459(24), 1470(22), 1472(12), 1474(11), 1500(25), 1550(27), 1628(7), 1859(17), 2383(2), 2385(26), 2391(11), 2402(3), 2456(13), 2508(12), 2511(19), 2715(16), 2735(13), 2741(19), 2744(5), 2745(15), 2746(2), 2747(8), 2780(16), 2781(12); Siqueira-Filho, J. et al. 497(19),939(6), 1013(6), 1426(6), 1446(19), 1458(6), 1479(19), 1501(19), 1512(1); Sobral-Leite, M. 235(13), 609(5), 1016(16); Sousa, G. \& Wanderley, M. 26(19); Sousa, G. 60(27), 86(12), 97(12), 126(19), 127(12), 148(24), 149(26), 159(8), 160(8), 164(26), 165(23), 166(23), 168(23), 169(21), 170(8), 171(8), 172(24), 176(7), 177(7), 178(7), 181(8), 182(23); Staviski, M. 1601(23); Staviski, M. et al. 973(19), 1019(23); Tavares, S. 60(11), 873(1), 1044(23); Thomas, W. 11693(3), 12458(12), 13187(26); Tomaz, E. 1(23), 2(23); Vasconcellos, J. 207(16), US-2059452(8); Viana, A. 255(11), 264(8), 268(16); Viana, J. 124(26); Wedermann, E. 2931(10); Xavier, L. JPB-1(23), JPB-2(16), JPB-5(23), JPB-7(8), JPB-8(16), JPB-9(8), JPB-781(8). 